\title{
THE RECOVERY OF A DEGRADED MANGROVE IN CEARÁ THROUGH THE PRODUCTION OF Laguncularia racemosa (L.) C.F. Gaertn. (Combretaceae) AND Avicennia sp. Stapf ex Ridl (Acanthaceae) SEEDLINGS ${ }^{1}$
}

\author{
Amanda Lídia de Sousa Paula ${ }^{2 *}$, Brena Késia de Sousa Lima² e Rafaela Camargo Maia
}

\begin{abstract}
${ }^{1}$ Received on 30.12.2014 accepted for publication on 07.03.2016.
${ }^{2}$ Instituto Federal do Ceará. Graduação em Ciências Biológicas, Acaraú, Ceará - Brasil. E-mail: <amandabio2015@gmail.com> and <brenakesia7@hotmail.com>.

${ }^{3}$ Instituto Federal do Ceará, Laboratório de Ecologia de Manguezais, Acaraú, Ceará - Brasil. E-mail: <rafaelamaia@ifce.edu.br>.

*Corresponding author.
\end{abstract}

\begin{abstract}
The mangrove ecosystem performs several natural functions of great ecological and economic importance. This study provided procedures for the recovery of mangrove ecosystems through the characterization of vegetation and zonation patterns and evaluation of growth and survival rates of mangrove species in an experimental plantation. The study was performed in the Acaraú River estuary mangrove on the western coast of Ceará State. The characterization of vegetation was conducted with the use of multiple plots and transects replication. Plants were identified at the species level, and their heights and CBH (circumference at breast height) were measured in each plot. Seedlings of the dominant mangrove species were produced using estuarine propagules. Five mangrove species were sampled: Rhizophora mangle, Avicennia germinans, Avicennia schaueriana, Laguncularia racemosa, and Conocarpus erectus. L. racemosa was the most dominant and frequent species, followed by $A$. germinas. A total of $111 \mathrm{~L}$. racemosa and 102 Avicennia sp seedlings of were produced. Seedlings were viable for replanting within two months. The results of the analysis of vegetation structure and production and growth of seedlings are encouraging and demonstrate that revegetation is not only possible but also successful in this significantly deforested and degraded mangrove.
\end{abstract}

Keywords: Vegetation structure; Seedlings; Experimental plantation.

\section{RECUPERAÇÃO DE UM MANGUEZAL DEGRADADO NO CEARÁ ATRAVÉS DA PRODUÇÃO DE MUDAS DE Laguncularia racemosa (L.) C.F. Gaerth. (Combretaceae) E Avicennia sp. Stapf ex Ridl (Acanthaceae)}

\begin{abstract}
RESUMO-O ecossistema manguezal desempenha diversas funções naturais de grande importância ecológica e econômica. Assim, o objetivo desse trabalho foi fornecer subsídios para recuperação do ecossistema manguezal, por meio da caracterização vegetal e dos padrões de zonação, além da avaliação das taxas de crescimento e sobrevivência das espécies de mangue em plantio experimental. Este estudo foi desenvolvido no manguezal do estuário do rio Acaraú, litoral oeste do estado do Ceará. A caracterização da estrutura vegetal do manguezal foi feita com o emprego de parcelas múltiplas, replicando os transectos. Em cada parcela, as plantas foram identificadas quanto à espécie, tiveram sua altura estimada e a CAP (circunferência na altura do peito) aferido. Após o estudo estrutural, foram produzidas mudas de mangue das espécies dominantes, utilizando propágulos do estuário. Foram amostradas cinco espécies de mangue: Rhizophora mangle, Avicennia germinans, Avicennia shaueriana, Laguncularia racemosa e Conocarpus erectus. A espécie L. racemosa foi dominante e a mais frequente, seguida por A. germinas. Destas duas, foram produzidas 213 mudas, sendo 111 mudas de L. racemosa e 102 de Avicennia sp. Os dados obtidos nesse estudo indicam que, em dois meses, os propágulos estavam viáveis para o replantio. Os resultados foram considerados
\end{abstract}


positivos, tanto na análise da estrutura vegetal, quanto à própria produção de mudas e ao sucesso do desenvolvimento e replantio, demonstrando que, mesmo este manguezal estando bastante desmatado e degradado é sim possível o sucesso do replantio.

Palavras-chave: Estrutura vegetal; Plântulas; Plantio experimental.

\section{INTRODUCTION}

Mangroves are one of the most important coastal environments in the tropics. They are characterized by typical woody vegetation (angiosperms) associated with other components of flora and fauna adapted to limiting conditions of salinity and unconsolidated substrate that is poorly oxygenated and frequently submerged by tides (SCHAEFFER-NOVELLI, 1995). This ecosystem performs several natural functions of great ecological and economic importance including the support of coastal food chains as a source of organic matter, and as refuge, feeding, and reproduction areas for many animal species including those with economic value (LACERDA, 1984; LUGO; SNEDAKER, 1974; VANNUCCI, 2001; NAGELKERKEN, 2002). Mangroves also protect coastal areas against erosion, acting as a barrier against the action of waves, tides, and winds, and immobilizing pollutants by functioning as a biofilter (LUGO; SNEDAKER, 1974; LACERDA, 1984; SCHAEFFER-NOVELLI et al., 2001).

Currently, the intensive use of natural resources threatens the existence of mangrove ecosystems, particularly because many of these coastal areas became major population and economic centers. The progressive deforestation of mangrove forests for timber harvesting causes various imbalances in the natural dynamics and is particularly noteworthy in the Northeastern states in Brazil where shrimp farming or production of fishing products have prospered at the expense of the mangrove forests (IBAMA, 2005; SILVA, 2006; ARAÚJO; FREIRE, 2007).

The vegetation structure of mangroves directly influences the conditions and functioning of mangrove forests, and therefore, its characterization is an important tool to indicate the ecosystem's responses to existing environmental conditions and to assist studies that aim at conservation (SOARES, 1999; CAVALCANTI et al., 2009; BLANCO-LIBREROS et al., 2013).

Mangrove trees require decades to achieve a certain structural maturity in areas with tensors or stressors (FERWERDA et al., 2007). These results were observed in mangroves in the Rio das Ostras estuary (RJ) where natural forests showed a better structure development compared to planted or restored forest areas (BERNINI et al., 2014). Thus, natural regeneration is not always sufficient to remedy problems or restore degraded mangroves. The cessation of human impact is needed to allow favorable conditions for mangrove regenerationand to allow restoration through planting or transplantation of dominant species (SHAEFFERNOVELLI, 1995). Therefore, the evaluation of heights, basal areas, species density, and frequency of mangrove trees, along with assessments of species zonation patterns in significant areas and characterization of the environment are necessary to indicate the most suitable species and best locations for seedling plantations.

The different plant species are distributed in mangroves in separate zones, which follow a tidal gradient (SHERMAN et al., 2000; LONDE et al., 2013.). Generally, the red mangrove, Rhizophora mangle (L.) (Rhizophoraceae), occupies locations near the sea, rivers, or muddy places while the black mangrove, Avicennia germinans (L.) Stearn (Avicenniaceae), and the white mangrove, Laguncularia racemosa (L.) Gaertn. (Combretaceae), dominate the locations distant from the water (LUGO; SNEDAKER, 1974). The button mangrove, Conocarpus erectus (L.), and facultative species of the genus Hibiscus, Acrostichum and Spartina, can occur. Because of the diversity of mangrove environments, this zonation pattern, although quite common, is not necessarily found in all locations. While this zonation is evident in the vegetation of open coastal areas, Bunt and William (1981) found a less frequent pattern in estuarine areas when overlapping species can occur

Thus, the aim of this study was to provide methods for the recovery of mangrove ecosystems in the municipality of Acaraú, on the western coast of Ceará State through the characterization of vegetation and zonation patterns in significant areas and to assess growth and survival rates of mangrove species in an experimental plantation. Specifically, we aim: 1) to 
characterize the vegetation structure of significant mangrove forests in the Acaraú River estuary by documenting the height, $\mathrm{DBH}$, and basal area of trees, as well as the frequency and relative dominance of various species; 2) to evaluate whether the specific composition and density of species in the studied mangrove presents a zonation pattern with respect to distance from the river; and 3 ) to produce mangrove seedlings of the dominant species in the region and evaluate growth and survival rates of individuals.

\section{MATERIALAND METHODS}

\subsection{Study area}

This study was conducted in the Acaraú River estuary mangrove, near the port area of the municipality of Acaraú (02\%49"94'S, 4005"14'W), off the western coast of Ceará - at about $260 \mathrm{~km}$ from the state capital, Fortaleza. The state has a territory of $148,016 \mathrm{~km}^{2}$, with about $570 \mathrm{~km}^{2}$ of coastal area; mangroves occupy an area of $182 \mathrm{~km}^{2}$, approximately $32 \%$ of the State's coastal territory (SEMACE, 2006). The Acaraú River rises in the Matas Mountains (Ceará central hinterlands) and ends in the city of Acaraú, forming the second largest river basin of Ceará, and covering twenty-five municipalities. In general, mangrove forests in this region occur in small areas and are limited to estuarine systems, where the impact of high salt concentration is lessened. High salt concentrations in these systems result from the dry climate which forms important hypersaline plains where areas sheltered from hydrodynamics are located (SCHAEFFER-NOVELLI et al., 2001).

\subsection{Methodology}

\subsubsection{Structural and zonation characterization}

The characterization of the mangrove vegetation structure used the multiple plot methodology proposed by Schaffer-Novelli and Cintrón (1986), with modifications to include transects replication (MAIA; COUTINHO, 2012). Three points were randomly selected at each site, and transects with five plots of $100 \mathrm{~m}^{2}$ each and spaced at $5 \mathrm{~m}$, were set in each point. The plots were set perpendicular to the river, and the first one was at 10 meters from the river margin.

In each plot, plants were identified at the species level, and heights and CBH (circumference at breast height $-1.30 \mathrm{~m}$ ) were measured with the aid of a measuring tape. The $\mathrm{CBH}$ data were transformed into diameter at breast height $(\mathrm{DBH}=\mathrm{CAP} / \pi)$ and average values of height, $\mathrm{DBH}$, basal area of individuals $\left(\pi / 4 . \mathrm{DBH}^{2}\right)$, the density of living and dead trunks, and relative frequency and dominance of species were calculated. Frequency is the percentage of plots with a given species and was calculated as follows: Relative frequency $=$ (frequency of a species/sum of the frequencies of all species) $x$ 100. Relative dominance is the percentage of the basal area of a species in relation to the basal area of all species and was calculated as follows: Relative dominance $=$ (relative dominance of a species $/$ total number of individuals) $\mathrm{x} 100$.

\subsubsection{Production of seedlings}

Seedlings of dominant species were produced using propagules collected in the estuary. Propagules were harvested directly from the parent tree or sediment and divided into the following stages: no germination, initial germination, and advanced germination. The germination stages were characterized by visual observations and based on Schaeffer-Novelli and Cintrón (1986). The fruits of Avicennia sp. species in the no germination stage were still enclosed in their two leathery closed valves. The two dehiscent valves were open in the 'initial germination' stage and showed the radicle with root hairs within the pericarp; the radicle was out of the propagule and showed some secondary roots in the 'advanced germination' stage. In Laguncularia racemosa, the fruit still remained closed in the "no germination' stage, and the fruits showed part of the radicle out of the endocarp base in the 'initial germination' stage; the radicle was totally out of the exocarp and presented secondary roots in the 'advanced germination' stage (Figure 1).

Each propagule was measured and placed in 1-liter polyethylene bags with the substrate (a mixture of muddy sediment from the mangrove with sand), maintained in a partly shaded area and irrigated daily with non-saline water. The muddy mangrove sediment was screened for decomposing animals, leaves, and branches before use. The seedlings were measured weekly, for eight weeks, with the aid of a caliper (accuracy $=0.05 \mathrm{~mm}$ ).

\subsubsection{Statistical analysis}

The Kruskal-Wallis test was used to compare trees' heights, DBH, and the basal area between plots and evaluate differences in growth rates of mangrove seedlings

Revista Árvore, Viçosa-MG, v.40, n.3, p.377-385, 2016

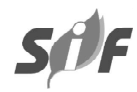


Source: author's photos. Fonte: Foto da autora

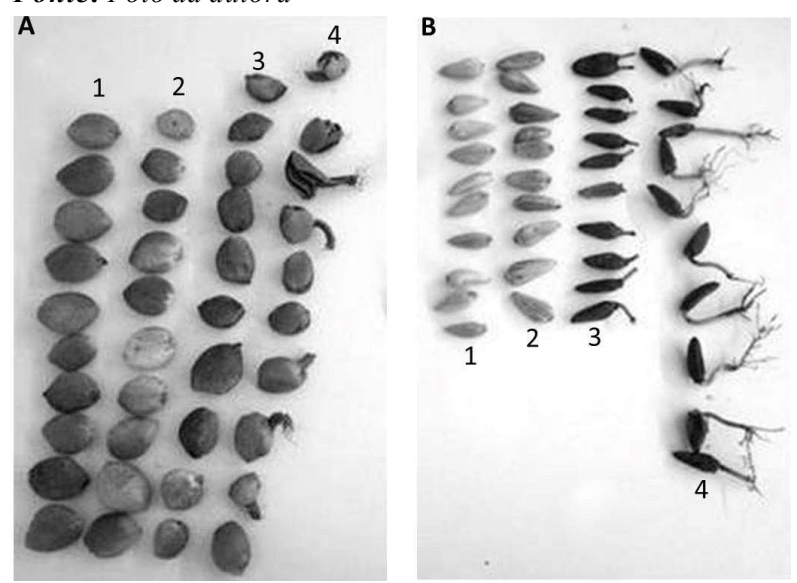

Figure 1 - Stage of Avicennia sp. (A) and Laguncularia racemosa $(\mathrm{B})$ seedlings: 1 - collected in the parent tree, 2- no germination stage, 3 - initial germination stage, and 4- advanced germination stage.

Figura 1 - Estágio dos propágulos de Avicennia sp. (A) e Laguncularia racemosa (B): 1-coletados na árvoremãe, 2- sem germinação, 3-germinação inicial e 4- germinação avançada.

at different germination stages. The multiple comparison test was used when differences were observed between samples. Analysis of variance (ANOVA) was used to assess differences in tree density or specific composition, and growth of seedlings at different germinating stages. All analyzes were performed using the STATISTICA program for Windows version 7.0.

\section{RESULTS}

\subsection{Structural and zonation characterization}

Five mangrove species were sampled in the study area in the Acaraú River estuary: red mangrove,
Rhizophora mangle, black mangrove, Avicennia germinans and Avicennia schaueriana, white mangrove, Laguncularia racemosa, and the button mangrove, Conocarpus erectus. Laguncularia racemosa was the most dominant (51.90\%) and frequent species (21.08\%) followed by $A$. germinans (dominance of $42.20 \%$, and frequency of $14 \%$ ). The other species presented low dominance and frequency values: $R$. mangle, $3.09 \%$ and $2.77 \%$; C erectus $2.55 \%$ and $1.96 \%$; and $A$. schaueriana $0.26 \%$ and $5.77 \%$, respectively.

The average total height of the studied forests was $3.44 \mathrm{~m}+2.27 \mathrm{~m}$, with anamplitude between 1.35 $\mathrm{m}$ and $13 \mathrm{~m}$ height. The overall average $\mathrm{DBH}$ was 4.46 $\mathrm{cm}+7.05 \mathrm{~cm}$, ranging from $0.31 \mathrm{~cm}$ to $62.42 \mathrm{~cm}$. Because the DBH values are used to calculate basal areas, these variables provide similar patterns. The total sampled basal area was $1.2290 \mathrm{~m}^{2}$, with a range from $0.0032 \mathrm{~m}^{2}$ to $0.6379 \mathrm{~m}^{2}$. A total of 17 individuals were dead in the sampling area, $10 \mathrm{~A}$. germinans and $7 \mathrm{~L}$. racemosa, all observed in plots one and two. The average height was $1.54 \mathrm{~m}+1.30 \mathrm{~m}$ and the $\mathrm{DBH}$ ranged between 0.95 $\mathrm{cm}+0.55 \mathrm{~cm}$ and $6.21 \mathrm{~cm}+4.87 \mathrm{~cm}$.

The species zonation did not show significant differences in the density of mangrove individuals $\left(\mathrm{F}_{2.6}\right.$ $=0.79043, \mathrm{p}=0.49579$ ) or in the specific composition between the sampled plots (Table 1). However, we observed that $L$. racemosa and $A$. germinans were present in all plots. $R$. mangle was found only in plot 2; C. erectus in plots 1 and 2. Although $A$. schaueriana occurred in three plots, only a small number of individuals were present (Figure 2).

The average height of trees varies significantly among the sampled plots $\left(\mathrm{H}_{2.6}=27.14617 ; \mathrm{p}<0.001\right)$; the highest mangrove trees were found close to the river (Figure 3A). The average DBH presented a similar

Table 1 - Results of the analysis of variance (ANOVA) comparing the specific composition of mangroves between plots in the Acaraú River estuary.

Tabela 1 - Resultados da Análise de Variância (ANOVA) comparando a composição específica de mangues entre as parcelas no estuário do rio Acaraú.

\begin{tabular}{lccr}
\hline & SPECIES COMPOSITION & & \multicolumn{1}{c}{$g l^{*}$} \\
\hline Avicennia germinans & $F$ & 2.6 & 0.85682 \\
Avicennia schaueriana & 0.15858 & 2.6 & 0.70947 \\
Conocarpus erectus & 0.36364 & 2.6 & 2.6 \\
Laguncularia racemosa & 0.94138 & 2.6 & 0.44098 \\
Rhizophora mangle & 0.91871 & 1.0000 & 0.42187 \\
\hline
\end{tabular}

* Gl= degrees of freedom

Source: Elaborated by the authors.

Fonte: Elaborada pelos autores.

Revista Árvore, Viçosa-MG, v.40, n.3, p.377-385, 2016 
distribution pattern, increasing with the distance from the river $\left(\mathrm{H}_{2.6}=53.55031 ; \mathrm{p}<0.001\right)$ (Figure $\left.3 \mathrm{~B}\right)$.

\subsection{Production of seedlings}

The structural study showed that Laguncularia racemosa and Avicennia sp. were the most common species; therefore, seedlings of these species were

Source: Elaborated by the authors Fonte: Elaborada pelos autores.

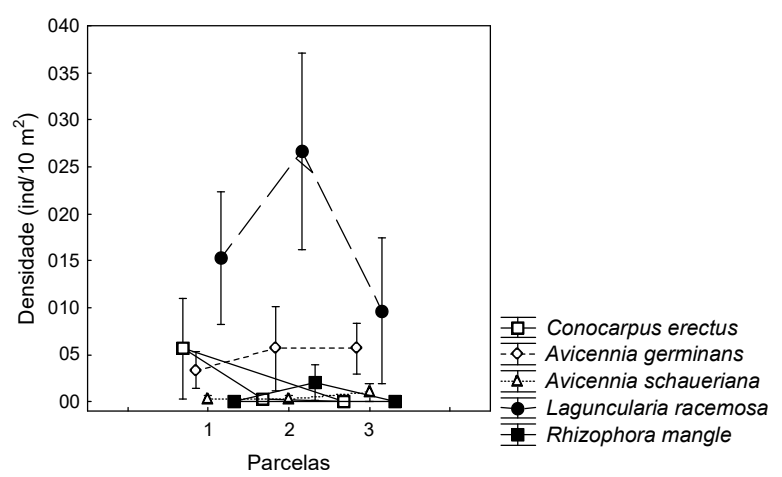

Figure 2 - Average density \pm standard deviation of mangrove species recorded between sampled plots in the Acaraú River estuary.

Figura 2-Densidade média \pm desvio-padrão das espécies de mangue registradas entre as parcelas de amostragem no estuário do rio Acaraú. produced. A total of 213 seedlings were produced, 111 of L. racemosa and 102 of Avicennia sp.; these numbers resulted from the availability of propagules found in the field. The mortality rates were variable during the study period, being $45.94 \%$ for L. racemosa and $7.84 \%$ for Avicennia sp.. The main cause of mortality was susceptibility to herbivory by ants.

During the study, L. racemosa showed growth from the second through the fifth week, with the highest average growth of $94.5 \mathrm{~mm}+39.0 \mathrm{~mm}$ (Figure 4A). Growth stabilization was observed at weeks 6,7 , and 8 . The lowest average development values were observed in the second week when many individuals suffered herbivory. Avicennia sp. seedlings showed progressive development between the first and fifth week when they reached the highest values and an average of $75.5 \mathrm{~mm}+22 \mathrm{~mm}$ growth (Figure 4B).

Avicennia sp. seedlings collected from the parent tree or at different germination stages from the sediment did not show significant differences in growth $\left(\mathrm{H}_{3.94}=\right.$ $5.044, \mathrm{p}=0.169)$ or L. racemosa $\left(\mathrm{H}_{3.60}=2.137, \mathrm{p}=0.546\right)$.

\section{DISCUSSION}

The studied mangrove area in the Acaraú River estuary is at a critical stage of degradation, suffering from landscape and ecosystem dynamics disfigurement

Source: Elaborated by the authors.

Fonte: Elaborada pelos autores.
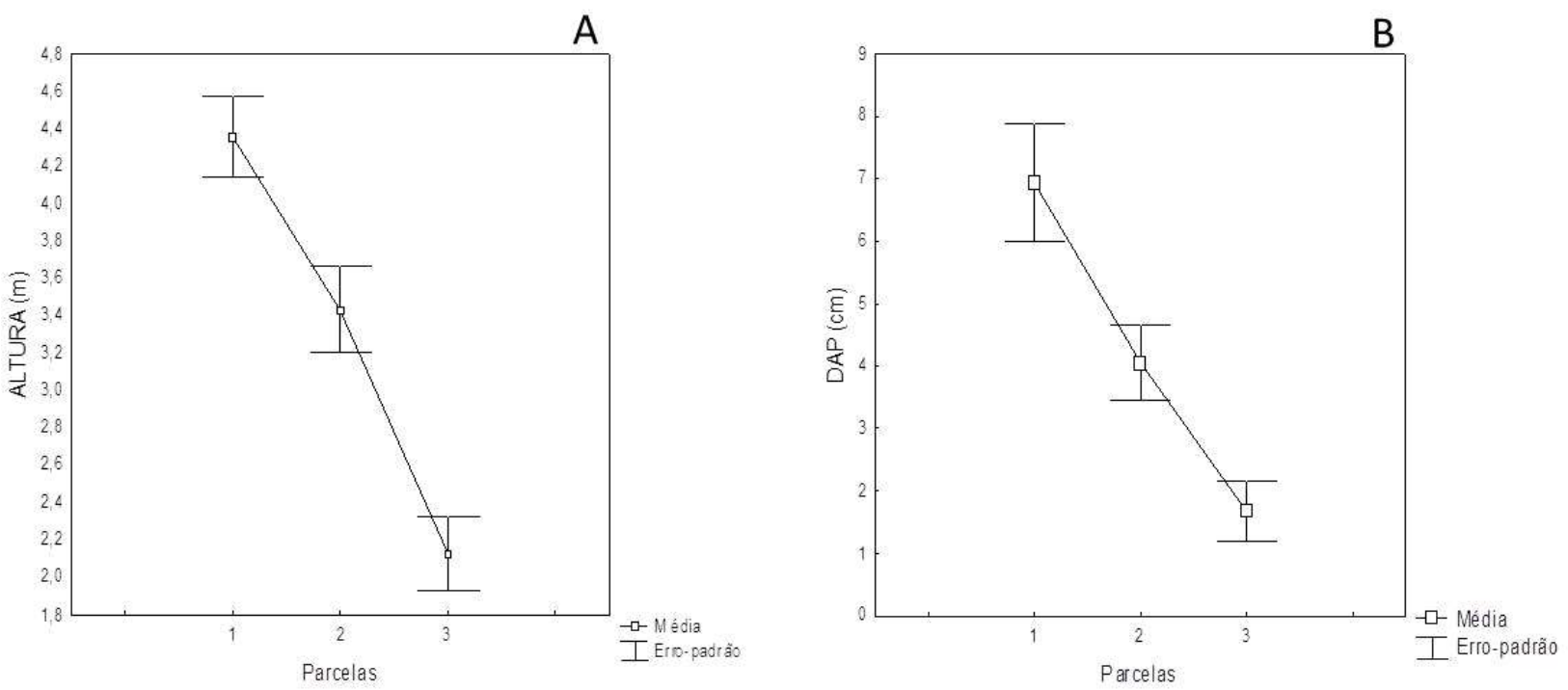

Figure 3 - Height (A) and DBH (B) average \pm standard deviation of trees between the studied plots.

Figura 3 - Altura (A) e DAP (B) médio \pm desvio-padrão das árvores entre as parcelas no estuário estudado. 
Source: Elaborated by the authors

Fonte: Elaborada pelos autores.
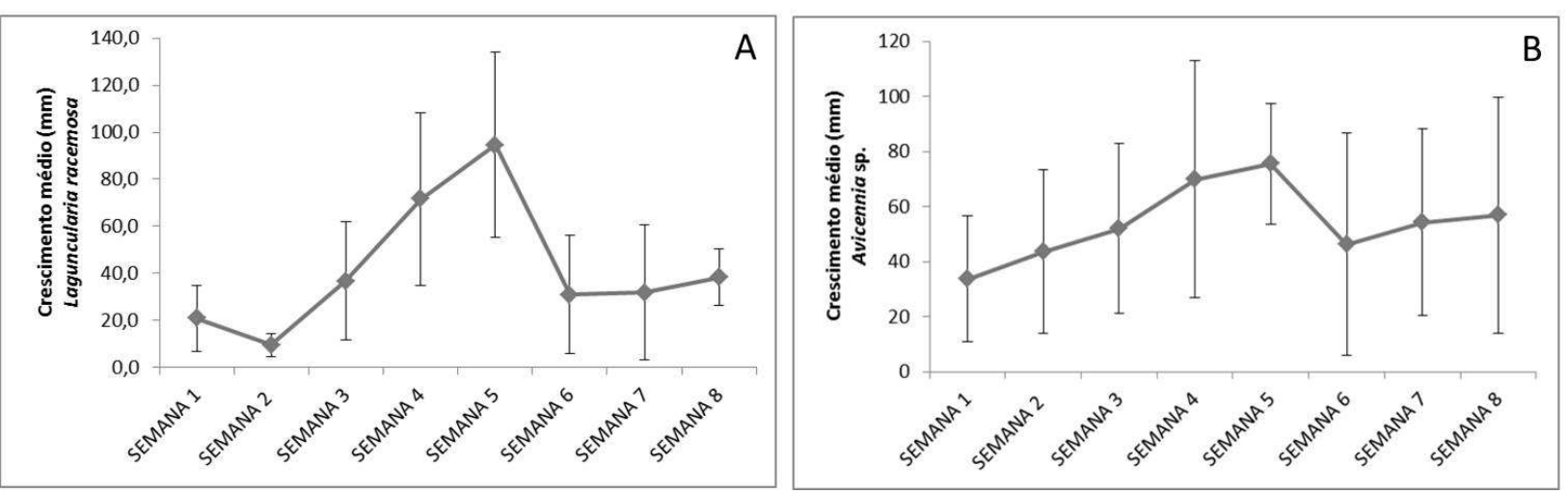

Figure 4 - Average growth (mm) of L. racemosa (A) and Avicennia sp. (B) \pm standard deviation during the eight weeks of the experimental plantation.

Figura 4-Crescimento médio (mm) de L. racemosa (A) e Avicennia sp. (B) \pm desvio-padrão durante as oito semanas de plantio experimental.

(IBAMA, 2005). The presence of cut off logs and garbage disposal were observed in all analyzed plots, a fact that threatens the existence of the mangrove ecosystem. Data acquired on the occurrence of species, the size and density of trees, and zonation patterns are characteristic of a damaged mangrove.

Laguncularia racemosa was found in high dominance and relative frequency values in the test area. Several studies indicate that this species is typical of degraded forests in the process of regeneration, and characterize it as a pioneer species in the process of secondary succession (PERIA et al., 1990; SOARES, 1999; SOUZA; SAMPAIO, 2001; SOARES et al., 2003; BERNINI; RESENDE, 2010). According to Smith III (1992), mangrove forests subjected to more frequent disturbances have lower numbers of Rhizophoraceae species compared to species such as Laguncularia racemosa. Petri et al. (2011) analyzed the vegetation structure of a mangrove forest in the Benavente River estuary (ES) and noted that the species $R$. mangle and $A$. schaueriana are dominant in areas with marine influence and longer flooding by tides while the species $L$. racemosa and A. germinans were dominant in areas of high influence of freshwater.

The greater the knowledge of the ecosystem's functions, the greater the chances of producing management plans and aiding its recovery (MENEZES, 2005; QUEIROZ et al., 2013.). As the result of the vegetation structure evaluation in this study, Laguncularia racemosa and Avicennia sp were chosen for the production of seedlings to be used in the restoration of degraded areas. Similar processes for the restoration of mangrove ecosystems have been used by several authors. Nascimento (2009) planted species in coastal areas under erosion in Campos de Serra and Macau$\mathrm{RN}$; Bonilla (2010), when working on mangrove recovery in the Sapiranga Reservation - CE, obtained a more than $50 \%$ survival of $L$. racemosa and A. germinans. Menezes (2005) conducted a pilot experiment with $R$. mangle and Laguncularia racemosa propagules in Cubatão - SP, and observed survival rates exceeding $70 \%$. Costa (2015) noted that L. racemosa seedlings in the city of Icapuí-CE related to a high resistance to adaptation to various levels of salinity.

It is known that destroyed mangroves can recover under favorable conditions when the presence of tensors responsible for the degradation ceases (PANITZ, 1997; LEWIS; STREEVER, 2000). However, natural regeneration is not always enough to solve the problems or save degraded mangroves, and human intervention is needed. According to Schaeffer-Novelli (1995), reshaping and/ or inducing restoration through sowing or transplanting seedlings of dominant species in the area to be restored is necessary in many cases. Lopes et al. (2013) analyzed the growth of seedlings in nurseries and in mangrove forests as a function of light and observed a high rate of viviparity in these two environments, which clearly indicates the phenotypic plasticity of these plants to adapt to existing environmental conditions. 
We were successful in planting L. racemosa and Avicennia sp of in the deforested and degraded Acaraú River estuary mangrove. This achievement will greatly contribute to the recovery of environmental and social quality in the region because the mangrove ecosystem provides a large number of goods and services. The data presented in this study emphasize the importance of reforestation and environmental awareness actions for the maintenance of the ecosystem (BLANCO; GUTIÉRREZ-ISAZA, 2014).

The number of studies on plantation and restoration of degraded mangrove areas in Brazil is small; however, the several experiments have been performed in Australia, Cuba, United States, and India (MENEZES, 1999).

\section{CONCLUSION}

The studied areas are significantly degraded. The vegetation structure of the mangrove was considered undeveloped, with a high dominance of L. racemosa, which is considered a resistant species in areas under actions of strong tensors. The data obtained in this study indicate that propagules of L. racemosa and Avicennia $s p$. obtained in the field are viable for replantation within a period of two months. Propagules already in development that were collected from the sediment or propagules in the final stages of development collected from the parent tree were also viable.

The results are positive, both with regard to the mangrove vegetation structure (given that L. racemosa is a species of secondary succession, which shows the mangrove's attempt to regenerate) and the successful production, development, and replanting of seedlings.

However, there is a lack of current baseline information to support the management of mangrove ecosystems, a lack which emphasizes the importance of studies on vegetation structure and reforestation in degraded areas. The adoption of a simple indicator to monitor environmental changes will be possible based on knowledge such as the forest structure.

\section{REFERENCES}

ARAÚJO, M.V.; FREIRE, G.S.S. Análise dos impactos ambientais causados em estuários: estudo do estuário do Rio Acaraú, Ceará - Brasil. Caminhos da Geografia, v.8, n.24, p.111$123,2007$.

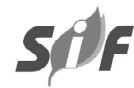

BERNINI, E.; REZENDE, C.E. Variação estrutural em florestas de mangue do estuário do Rio Itabapoana, ES-RJ. Biotemas, v.23, n.1, p.49-60, 2010.

BERNINI, E.; SANTOS, C.F.N.R.; LAGE-PINTO, F.; CHAGAS, G.P.; REZENDE, C.E. Fitossociologia de florestas de mangue plantadas e naturais no estuário do Rio das Ostras, Rio de Janeiro, Brasil. Biotemas, v.27, n.1, p.37-48, 2014.

BLANCO, J.F.; GUTIÉRREZ-ISAZA, N. Leaf litter mass loss rates and associated fauna of tree species commonly used in neotropical riparian reforestation. Acta Biologica Colombiana, v.19, n.1, p.91-100, 2014.

BLANCO-LIBREROS, J.F.; TABORDA-MARÍN, A.; AMORTEGUI-TORRES, V.; ARROYAVE-RINCÓN, A.; SANDOVAL, A.; ESTRADA, E. A.; LEALFLÓREZ, J.; ARANGO, J. G.V.; NARVÁEZ, A. V. Deforestácion y sedimentación em los manglares del Golfo de Urabá. Gestión yAmbiente, v.16, n.1, p.19-36, 2013.

BONILLA, O. H.; MAJOR, I.; MARTINS, M. O.; HERBSTEN NETO, A. G. Técnicas de plantio de espécies de Mangue num fragmento florestal degradado na reserva ecológica particular de Sapiranga - Fortaleza - CE. Journal Integration Coastal Zone Management, v.2, 2010.

BUNT, J.S.; WILLIAMS, W.T. Vegetational relationships in the mangroves of tropical Australia. Marine Ecology Progress Series, v.4, p.349-359, 1981.

CAVALCANTI, V.E.; SOARES, M.L.G.; ESTRADA, G.C.D.; CHAVES, F.O. Evaluating mangrove conservation through the analysis of forest. Journal Costal Research, v.56, p.390-394, 2009.

COSTA, L.R. Uso de águas hipersalinas na produção de mudas de mangue Laguncularia racemosa (L.) Gaertn. 2015. 100f. Dissertação de Mestrado (Manejo de Solo e Água) - Universidade Federal Rural do SemiÁrido, Mossoró, 2015.

IBAMA. Diagnóstico da atividade de carcinicultura no Estado do Ceará. Fortaleza: 2005.

Revista Árvore, Viçosa-MG, v.40, n.3, p.377-385, 2016 
FERWERDA, J. G.; KETNER, P.; MCGUINNESS, K. A. Differences in regeneration between hurricane damaged and clearcut mangrove stands 25 years after clearing. Hydrobiologia, v. 591, p. 35-45, 2007.

LACERDA, L.D. Manguezais: florestas de beira mar. Ciência Hoje, v.3, p.63-70, 1984.

LEWIS, R.R.; STREEVER, B. Restoration of mangrove habitat. WRP Technical Notes Collection. 2000. p.1-7.

LOPES, E.C.; ARAÚJO, E.C.; COSTA, R. S.; DAHER, R.F.; FERNANDES, M.E.B. Crescimento de mudas de mangue sob diferentes níveis de sombreamento na península de Ajuruteua, Bragança, Pará. Acta Amazonica., v.43, n.3, p.291-296, 2013.

LONDE, V.; SALLES, D.B.; LEITE, M.G.P.; ANTONINI, Y. Estrutura da vegetação de mangue associada ao gradiente de inundação no litoral norte do Espírito Santo, Brasil. Revista Árvore, v.37, n.4, p.629-637, 2013.

LUGO, A.E.; SNEDAKER, S.C. The ecology of mangroves. Annual Review Ecology Systems, v.5, p.39-64, 1974.

MAIA, R.C.; COUTINHO, R. Structural characteristics of mangrove forests in Brazilian estuaries: A comparative study. Revista de Biología Marina y Oceanografía, v.47, n.1, p.87-98, 2012.

MENEZES, G. V. Recuperação de manguezais: um estudo de caso na Baixada Santista, estado de São Paulo, Brasil. 1999. 145f. Tese (Doutorado em Oceanografia Biológica) - Universidade de São Paulo, São Paulo, 1999.

MENEZES, G. V.; SCHAEFFER-NOVELLI, Y.; POFFO, I. R. F.; EYSINK, G. G. J. Recuperação de manguezais: um estudo de caso na Baixada santista de São Paulo, Brasil. Brazilian Journal of Aquatic Science and Technology, v.9, v.1, p.67-74, 2005.

NAGELKERKEN, I.; ROBERTS, C.M.; VAN DER VELDE, G.; DORENBOSCH, M.; VAN RIEL, M. C.; COCHERET DE LA, M . E.; NIENHUIS, P. H. How important are mangroves and seagrass beds for coral-reef fish? The nursery hypothesis tested on an island scale. Marine Ecology Progress Series, v.244, p.299-305, 2002

NASCIMENTO, M.C. A erosão e sua influência sobre a atividade petrolífera: alternativas sustentáveis na mitigação de impactos ambientais. Dissertação. 222f. (Mestrado em Geofísica e Geodinâmica) - Universidade Federal do Rio Grande do Norte, Natal, 2009.

PANITZ, C.N.M. Ecological description of the Itacorubi mangrove, Ilha de Santa Catarina, Brazil. In: KJERVFE, B.; LACERDA, L.D.; DIOP, E.H. Mangrove ecosystem studies in Latin America and Africa. Paris: ISME UNESCO, 1997. p.204-224.

PERIA, L. C. S., FERNANDES, P. P. C. P., MENEZES, G. V., GRASSO, M.; TOGNELLA, M. M. P. Estudos estruturais comparativos entre bosques de manguezais impactados (Canal da Bertioga) e não impactados (Ilha do Cardoso), estado de São Paulo. In: SIMPÓSIO DE ECOSSISTEMAS DA COSTA BRASILEIRA. Estrutura, função e manejo, 1990; Águas de Lindóia: Aciesp, 1990.

PETRI, D.J.C.; BERNINI, E.; SOUZA, L.M.; REZENDE, C.E. Distribuição das espécies e estrutura do manguezal do Rio Benevente, Anchieta, ES. Biota Neotropica, v.11, n.3, p.1-10, 2011.

QUEIROZ, M.C.S.; VILHENA, T.S.; MELHIG, U.L.F.; MENEZES, M.P.M. Análise de crescimento de Laguncularia racemosa (Combretaceae) em manguezal da resex caeté-taperaçu. In: CONGRESSO NACIONAL DE BOTÂNICA, 64 ., 2013, Belo Horizonte. Belo Horizonte: 2013.

SCHAEFFER-NOVELLI, Y.; CINTRÓN, G. Guia para estudo de áreas de manguezal; estrutura, função e flora. São Paulo: Caribbean Ecological Research, 1986. 150p.

SCHAEFFER-NOVELLI, Y. Manguezal; ecossistema entre a terra e o mar. São Paulo: Caribbean Ecological Research, 1995. 64p.

SCHAEFFER-NOVELLI, Y.; COELHO JUNIOR, C.; TOGNELLA-DE-ROSA, M. Manguezais. São Paulo: Ática, 2001. 
SHERMAN, R.E.; FAHEY, T.J.; BATTLES, J.J. Small-scale disturbance and regeneration dynamics in a neotropical mangrove forest. Journal of Ecology, v. 88, n.1, p.165-178, 2000.

SEMACE. Manguezais do nordeste do Brasil. Avaliação das áreas de manguezais dos Estados do Piauí, Ceará, Rio Grande do Norte, Paraíba e Pernambuco. Fortaleza: 2006.

SILVA, E.V. Principais formas de uso e ocupação dos manguezais do estado do Ceará. Culture and Science, v. 1, n.1, p.12-20, 2006.

SOARES, M.L.G.; CHAVES, F.O.; CORRÊA, F.M.; SILVA JÚNIOR, C.M.G. Diversidade estrutural de Bosques de Mangue e sua relação com distúrbios de Origem Antrópica: o caso da Baía de Guanabara (Rio de Janeiro). Anuário do Instituto de Geociências, v.26, p.101-112, 2003.

SOARES, M. L. G. Estrutura vegetal e grau de perturbação dos manguezais da Lagoa da Tijuca,
Rio de Janeiro, RJ, Brasil. Revista Brasileira de Biologia, v. 59, p. 503-515, 1999.

SOUZA, M.M.A.; SAMPAIO, E.V.S.B. Variação temporal da estrutura dos bosques de mangue de Suape - PE, após a construção do porto. Acta Botania Brasilica, v. 15. n.1, p.1-12, 2001.

SMITH III, T.J. Forest structure. In: ROBERTSON, A.I.; ALONGI, D.M. Tropical mangrove ecosystems. Washington: American Geophysical Union, 1992. p.101-136.

PIRES, I.O. Monitoramento de Manguezais da APA Guapimirim, RJ, através de correlação de dados de fitomassa e radiancia TM/ LANDSAT. Tese de doutorado. IFCH da USP. São Paulo, abril de 1992.

VANNUCCI, M. What is so special about mangroves? Brazilian Journal of Biology, v.61, p.599-603, 2001 . 